\title{
The failure of intravenous urea to alter the blood flow through the cerebral cortex
}

\author{
A. MURRAY HARPER AND RUTH A. BELL \\ From the University Department of Surgery, Glasgow Royal Infirmary
}

In 1956 Javid and Settlage demonstrated the efficacy of intravenous urea in reducing intracranial pressure and brain volume. Since then it has become widely used in the management of cerebral oedema and for improving access in intracranial operations. The following experiments were designed to determine whether intravenous urea affects the blood flow and oxygen consumption of the cerebral cortex.

\section{METHOD}

The experiments were performed on five unselected mongrel dogs. The anaesthetic used was pentothal and a 4:1 mixture of nitrous oxide and oxygen delivered through a respiratory pump. The brain cortex was exposed through a trephine hole made over the parietal lobe and a piece of dura $1 \mathrm{~cm}$. in diameter excised and replaced by $a$ thin cellophane membrane. Cannulae were placed in the sagittal sinus, the superior thyroid branch of the carotid artery and the femoral artery, the latter cannula being connected to a mercury manometer.

The method of measuring the blood flow through the cortex was that devised by Lassen and Ingvar (1961). A solution of Krypton 85 in dextran was injected slowly into the carotid artery via the cannula in the thyroid artery. The blood flow was calculated from the rate of clearance of the isotope from the brain cortex, this being measured by a Geiger counter mounted above the cortex.

After each blood-flow estimation, blood samples were taken from the aorta and sagittal sinus for the estimation of carbon dioxide tension and oxygen content. The former was measured on an Astrup apparatus (Astrup, 1956) and the latter calculated from the oxygen saturation (measured on a Kipp haemoreflector) and the haemoglobin content. The oxygen uptake of the brain cortex was calculated from the difference between the blood flow and the arteriovenous oxygen.

In each animal three control measurements of blood flow and oxygen uptake were made at approximately 20minute intervals. Then $1.5 \mathrm{~g} . / \mathrm{kg}$. body weight of lyophilized urea in $10 \%$ invert sugar (Urevert) was administered over 10 minutes. Thereafter further estimations of blood flow and oxygen uptake were made at intervals of five, 30 , and 60 minutes.

\section{RESULTS}

Within five to 10 minutes of the administration of urea a dramatic shrinkage of the brain was observed. This reduction persisted for about an hour; thereafter the brain began to recover its normal volume. There was a transient rise in blood pressure of 10 to $20 \mathrm{~mm}$. $\mathrm{Hg}$ immediately after the urea was given. In four dogs a rise in arterial $\mathrm{pCO}_{2}$ of about $5 \mathrm{~mm}$. $\mathrm{Hg}$ was observed. Thirty minutes after the administration of the urea, the $\mathrm{pCO}_{2}$ had returned to the control level. Tables I and II show the effect of the urea on the blood flow and the oxygen uptake of the brain cortex. No obvious change in either the blood flow or the oxygen uptake was noted after the administration of urea.

The mean values for the estimations of blood flow before the administration of urea were $0.58,0.59$, and $0.62 \mathrm{ml} . / \mathrm{g}$. $/ \mathrm{min}$. The mean values for the estimations of blood flow five minutes after the administration

TABLE I

BLOOD FLOW THROUGH BRAIN CORTEX BEFORE AND AFTER ADMINISTRATION OF INTRAVENOUS UREA

\begin{tabular}{|c|c|c|c|c|c|c|}
\hline \multirow{2}{*}{$\begin{array}{l}\text { Experiment } \\
\text { No. }\end{array}$} & \multicolumn{3}{|l|}{ Before Urea } & \multicolumn{3}{|l|}{ After Urea } \\
\hline & $\begin{array}{l}\text { Blood Flow } \\
\text { (ml./g./min.) }\end{array}$ & $\begin{array}{l}\text { Blood Flow } \\
\text { (ml./g./min.) }\end{array}$ & $\begin{array}{l}\text { Blood Flow } \\
\text { (ml./g./min.) }\end{array}$ & $\begin{array}{l}+5 \text { Minutes } \\
\text { Blood Flow } \\
(\text { ml./g./min. })\end{array}$ & $\begin{array}{l}+30 \text { Minutes } \\
\text { Blood Flow } \\
(\mathrm{ml} . / \mathrm{g} . / \mathrm{min} .)\end{array}$ & $\begin{array}{l}+60 \text { Minutes } \\
\text { Blood Flow } \\
\text { (ml./g./min.) }\end{array}$ \\
\hline $\begin{array}{l}1 \\
2 \\
3 \\
4 \\
5\end{array}$ & $\begin{array}{l}0.50 \\
0.62 \\
0.48 \\
0.66 \\
0.64\end{array}$ & $\begin{array}{l}0.60 \\
0.72 \\
0.45 \\
0.55 \\
0.61\end{array}$ & $\begin{array}{l}0.62 \\
0.72 \\
0.53 \\
0.63 \\
0.59\end{array}$ & $\begin{array}{l}0.72 \\
0.76 \\
0.40 \\
0.56 \\
0.59\end{array}$ & $\begin{array}{l}0.60 \\
0.66 \\
0.54 \\
0.57 \\
0.60\end{array}$ & $\begin{array}{l}0.65 \\
0.64 \\
0.47 \\
0.59 \\
0.57\end{array}$ \\
\hline Mean & 0.58 & 0.59 & 0.62 & 0.61 & 0.59 & 0.58 \\
\hline
\end{tabular}


TABLE II

OXYGEN UPTAKE OF BRAIN CORTEX BEFORE AND AFTER ADMINISTRATION OF INTRAVENOUS UREA

Experiment

No.

Before Urea

\begin{tabular}{lll}
\hline$O_{2}$ Uptake & $O_{2}$ Uptake & $O_{2}$ Uptake \\
$($ ml./g./min. $)$ & (ml./g./min.) & (ml./g./min.)
\end{tabular}

After Urea

$\begin{array}{lll}+5 \text { Minutes } & +30 \text { Minutes } & +60 \text { Minutes } \\ O_{2} \text { Uptake } & \mathrm{O}_{2} \text { Uptake } & \mathrm{O}_{2} \text { Uptake }\end{array}$

(ml./g./min.)

(ml./g./min.)

0.049

0.059

0.037

0.036

0.045
0.051

0.075

0.066

0.032

0.056
$\mathrm{O}_{2}$ Uptake (ml./g./min.)

0.054

0.065

0.062

0.042

0.056 of urea were $0.61 \mathrm{ml} . / \mathrm{g} . / \mathrm{min}$., after 30 minutes $0.59 \mathrm{ml} . / \mathrm{g} . / \mathrm{min}$., and after 60 minutes $0.58 \mathrm{ml} . / \mathrm{g} . /$ min. Similarly the mean values for oxygen uptake in the control estimations were $0.048,0.053$, and $0.055 \mathrm{ml} . / \mathrm{g} . / \mathrm{min}$. Five minutes after the urea the oxygen uptake of the brain cortex was $0.045 \mathrm{ml} . / \mathrm{g} . /$ min., after 30 minutes $0.056 \mathrm{ml} . / \mathrm{g} . / \mathrm{min}$., and after 60 minutes $0.056 \mathrm{ml} . / \mathrm{g}$. $/ \mathrm{min}$. These differences lie within the experimental error and are not significant.

\section{CONCLUSION}

In spite of the marked decrease in brain volume which occurs after the administration of urea, there is no significant change in the blood flow through the brain cortex or in the oxygen uptake of the brain cortex.

This work was carried out in the University Department of Surgery, Glasgow Royal Infirmary, and the WellcomeResearch Laboratories, University of Glasgow, under. the direction of Professor W. A. Mackey. The work was supported by a grant from the Medical Research Council. $\omega$ We are grateful to Professor Mackey for his help and 5 advice in preparing this communication. The Urevert was supplied by Baxter Laboratories Ltd. Valuablei technical assistance was rendered by Miss Margaret. Anderson, Miss Elizabeth Johnstone, and Miss Elizabeth. Shuttleton.

\section{REFERENCES}

Astrup, P. (1956). Scand. J. clin. Lab. Invest., 8, 33. Javid, M., and Settlage, P. (1956). J. Amer. med. Ass., 160, 943. Lassen, N. A., and Ingvar, D. H. (1961). Experientia (Basel), 17, 